\title{
The Unpublished Funerary Votive Stela of Horwedja 'JE 99108' in the Egyptian Museum, Cairo
}

Dr.Heba Maher

\begin{abstract}
:
This article deals with an unpublished stela (JE. 99108). It found at north Saqqara in Serapeum area. It is a round-topped limestone stela with measures $16 \mathrm{~cm}$ in high, $3.5 \mathrm{~cm}$ in width and 9.5 in depth, depicts a traditional funerary scene of offering for Apis with two texts in the lower part of the stela. Based on stylistic features, the stela can be dated to the $26^{\text {th }}$ or $27^{\text {th }}$ dynasty. At first, a description of the stela will be presented, followed by notes on the significance of the scene, then a transliteration, a translation and a comment on the texts. Finally, the stela is fascinating because of the good quality of workmanship, the clear arrangement of figures and hieroglyphic text, unless the demotic text which is extremely damaged.
\end{abstract}

Key Words: Stela - Apis bull- Saqqara - Serapeum - animals cult- Winged Sun disk- 'Horus-Behdetite'.

I. Details of the Stela: ${ }^{1}$

- Location and Number: Egyptian Museum in Cairo 'JE 99108'. ${ }^{2}$

- Main Person(s): Horwedja- Apis Bull. ${ }^{3}$

- Provenance: Saqqara ${ }^{4}-$ Serapeum area. ${ }^{5}$

- Material: Limestone round topped stela. ${ }^{6}$

\footnotetext{
${ }^{1}$ These details are according to the database of Egyptian Museum in Cairo.

${ }^{2}$ The number of the stela in the excavation reports of the German Mission in 1985 was R. No. 18388. It moved to the Egyptian Museum in 3/9/2002, and entered in the Journal d'entrée database as JE 99108.

${ }^{3}$ Apis bull was the most important of the sacred animals. Apis is mentioned in texts as early as the $1^{\text {st }}$ Dynasty. The earliest attestation is found on a bowl of porphyritic diorite, whose inscription mentions the first occasion of the running of the Apis under king Aha, thus demonstrating that a cult involving the bull (not necessarily a cult of the bull) had already been practiced during the rule of the first. So, during the Early Dynastic period, as well as the Old Kingdom era, the Apis bull was perhaps predominantly used as a processional animal, symbolizing the fertility of crops and fields and agricultural rejuvenation, and associated with the periodic celebrations of royal public festivals at Memphis, like the Sed-festival or the king's coronation. The organized cult of the divine Apis bulls appears in surviving sources only from the mid-second millennium B.C. onwards, but his association with the god Ptah of Memphis came later, when he is described as the ba or 'herald' (wehem) of Ptah. See, J. H. Taylor, Death and the Afterlife in Ancient Egypt (London, 2001), 247; W. K. Simpson, 'A running of the Apis in the reign of 'Aha and passages in Manetho and Aelian', Orientalia 26 (1957), 139-142; C. Jurman, Running with Apis The Memphite Apis Cult as a Point of Reference for Social and Religious Practice in Late Period Elite Culture, in: Bares et al (eds.), Egypt in Transition (Prague, 2010), 225. For a recent survey of this Memphitic cult, with focus on the Ptolemaic period see, D. J. Thompson, Memphis under the Ptolemies (Princeton, 1988), 190-211.

${ }^{4}$ The Saqqara necropolis was the important site of the burials of the sacred Apis bulls and other sacred animals, and the location of their associated temples and structures. The earliest known burial for the sacred bull at this site is dated to the reign of Amenhotep III (C.1390-1353 BC). However, it is possible that earlier burials have either not yet been discovered or may have been destroyed. The reason for the location of these burials on the Saqqara necropolis was due to the theological understanding that the Apis bull was the emanation of the Memphite creator god Ptah. During the Late Period developments in Egypt impacted on the cult at Saqqara. See, J. Labudek, Late Period Stelae from Saqqara; A socio-Cultural and Religious Investigation (MA. diss., The University of Birmingham, 2010), 10; N. Marković, 'A look through his window: the sanctuary of the divine Apis Bull at Memphis', JAEA 1(2016) 59.

${ }^{5}$ At first, The burials of the Apis was in separate chambers, and later in rooms opening off subterranean catacombs. The deceased Apis was identified with Osiris, and was referred to as Osiris-Apis or Osorapis. This name gave rise to the Graecised Serapis, and from this, the burial galleries at Saqqara became known as the Serapeum. The Serapeum remained in use from the New Kingdom to the Ptolemaic Period, although not all the burial places of the bulls from this long time-span have been identified. See, Taylor, Death and the Afterlife, 248.
} 
- Dimensions: Height $16 \mathrm{~cm}$, Width $3.5 \mathrm{~cm}$, Depth $9.5 \mathrm{~cm}$.

- Technique: Painted limestone. Hieroglyphic text in sunken relief.

- Dating: $26^{\text {th }}$ or $27^{\text {th }}$ dynasty.

- Genealogical stela: the formula $i m 3 h(w) h r h p$-Wsir followed by the name of the dedicant of the stela and of his family.
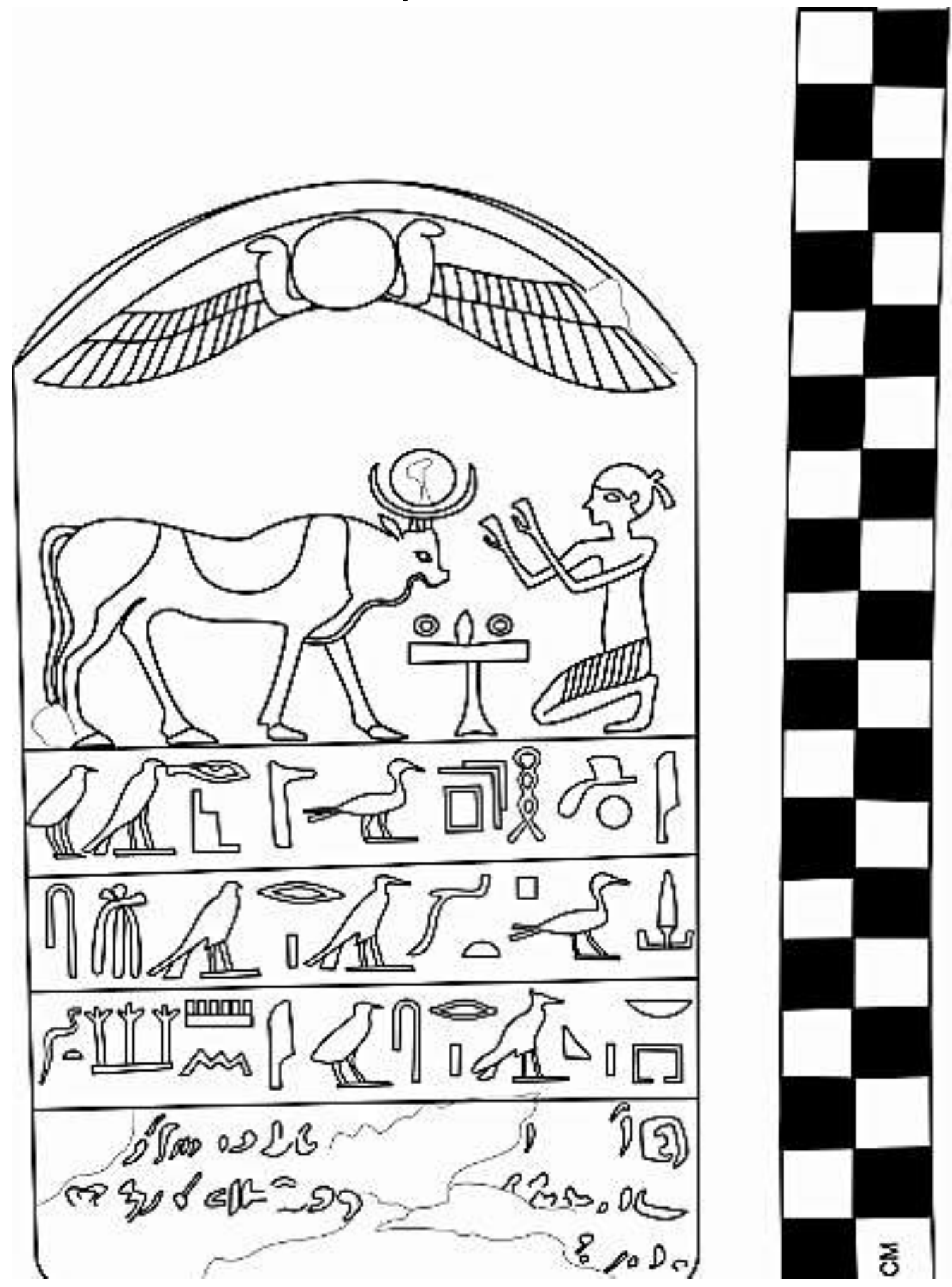

(fig.1)

${ }^{6} \mathrm{R}$. Hölzl, 'Stelae', in: Oxford Encyclopedia of Ancient Egypt III (Oxford, 2001), 319-324; K. Martin, 'Stele', L̈̈ VI, col. 1-6. 
The inscriptions from Serapum can be divided into two categories: (1) the official hieroglyphic stelae for the individual bulls dedicated by the kings, and (2) the unofficial private dedications set up by different kinds of priests (stelae in hieroglyphic or hieratic script), masons and other workers in the burial vaults (stelae and graffiti in demotic with some in hieroglyphic and demotic). ${ }^{7}$ So, this stela belongs to the second category. It displays three registers: (i) pictorial depictions in the upper one, (ii) three horizontal lines of an incised hieroglyphic inscription in the middle with horizontal lines between each line of hieroglyphic, and (iii) three horizontal lines of demotic inscription. The lower register in the stela is extremely damaged.

\section{The Upper Section (Lunette):}

It is a rounded Lunette ${ }^{8}$, decorated by a winged sun disc with a cobra in each side. ${ }^{9}$ It is known that the winged sun-disk is one of the most important protective symbols in ancient

\footnotetext{
${ }^{7}$ The proportion of preserved stelae is around $40 \%$ in hieroglyphic, around $10 \%$ in hieratic and around $50 \%$ in demotic script. These were hundreds of stelae inscribed in hieroglyphic, hieratic and demotic, set up by private individuals to express their piety and devotion to the Apis bull. Many of these stelae were set into the walls of the corridors, where they would be seen by visitors to the Serapeum. See, N. Marković, 'The Cult of The Scared Bull Apis: History of Study', in: A History of Research into Ancient Agyptian Culture Conducted in Southeast Europe, ed. M. Tomorad (Oxford, 2015), 138; Taylor, Death and the Afterlife, 248.

${ }^{8}$ The Stelae with a rounded lunette are documented through the Eleventh Dynasty. Müller divided the ancient Egyptian stelae in terms of shapes and places into three groups. (i) The form of the stelae of $1^{\text {st }}$ dynasty kings in Abydos, which were held independently and their late forms were based on a vertical wall, (ii) The developed form from offering niches in the outer wall of the tomb in the 2nd Dynasty in which the offerings were represented. From the $5^{\text {th }}$ Dynasty demonstrated on both sides with a rounded statement, and Cornice from the top, which is already a tradition of Bous buildings, and (iii) The indifferent form that do not belong to the previous two forms, and acquires its importance from the scenes and inscriptions, and must distinguish between tomb stelae, that distinguish the tombs known since the $1^{\text {st }}$ Dynasty, which may consider tombstone which do not carry only the deceased name and the depiction of him, but determined as well as the place of offerings, and the monuments related to persons or certain events, especially that with a religious meaning that were common in the Middle Kingdom. See, H. W. Müller, 'Die Totengedenksteine des Mittleren Reiches, ihre Genesis, ihre Darstellungen und ihre Komposition', MDAIK 4 (1933), 165-206; M. El-Toukhy, 'Protection Symbols on The Top of The Middle Kingdom Stelae (in Cairo Museum)', EJARS 3 (2013), 132. For more shapes of roundtopped stelae see, R. Hölzl, 'Round-Topped Stelae from the Middle Kingdom to the Late Period, Remarks on the Decoration of the Lunettes', SCIE I (1992), 285-290.

${ }^{9}$ This rounded Lunette with the winged sun disc are the most common decoration in many Apis Stelea such as Apis stelae of stèles du Sérapéum de Memphis I (Paris, 1968), 37 Nr. 37, pl. xii; 130-131 Nr. 169, pl.xlvi nr.169; 134 Nr. 174 , pl xlvii; 135 Nr. 176, pl xlviii. Compare the place of ureaus serpents with the stela which dedicated to Apis bull by a man named Padebehu(en)aset. It is Probably dated to the $26^{\text {th }}$ Dynasty (664-525 BC). See, Taylor, Death and the Afterlife, 250 fig. 184; Compare it also with Apis Stela Louvre IM. 4017; J. Vercoutter, Textes biographiques du Sérapéum de Memphis; Contributions à l'étude des stèles votives du Sérapéum (Paris, 1962), 59-64 Doc. H, pl. viii.
} 
Egypt. ${ }^{10}$ It appeared in Egyptian Art before it was directly associated with 'Horus the

Behdetite'. It is perhaps the most familiar and most distinctive symbols of 'Horus the Behdetite'. ${ }^{11}$

\section{The Main scene:}

It depicts a traditional funerary offering scene for Apis Bull, as it was the emanation and embodiment of the god Ptah. ${ }^{12}$ The devotee is shown with tied short hair, one ear shown clearly, and a large eye. The upper part of his body is exposed, and he wears a short kilt. He is kneeling raised his hand in adoration. There is an offering table contains two round loaves of bread between him and Apis Hepu ${ }^{13}$, which is in his standing form with white and black

\footnotetext{
${ }^{10}$ The early images do not bear the name of any other god. This creates some ambiguity as to the identity of the winged sun disk. See, R. L. Shonkwiler, The Behdetite: A Study of Horus The Behdetite from The Old Kingdom to The Conquest of Alexander (Ph. D. diss., Chicago, 2014), 63-64.

${ }^{11}$ The sun-disk is used in the ancient Egyptian Art in many different forms of metaphorical expression of concepts associated with solar faith, and the winged sun disk in one of its most common forms. Winged sundisk seems to be appeared first in third dynasty, and on the top of rounded stelae from the Middle kingdom. It reflects the union earths, which symbolize the two wings to Upper and Lower Egypt, the same idea appears in decorating the sun disk by couple of uraei. It decorates top of rounded stelae, rarely rectangular and of irregular shape. Usually was above a scene a God for the protection of the gods. There are only two winged sun disk forms appeared from Middle Kingdom Stelae: (i) The simple form $\square 0$ committed with couple of uraei Q $\odot 5$, perhaps the wings protects the scene and the uraei protects the sundisk, which appeared in few examples, (ii) The last form with long uraei in one "TF". See, M. Alam, 'Kors El-shams (Al-Moganah) zo el-genah alwahed wa ain al-wogadat ala kemam al-lawhat', CAHIER 37 (2008), 103-104; El-Toukhy, EJARS 3 (2013), 133

${ }^{12}$ L. Depuydt, 'Murder in Memphis: The Story of Cambyses's Mortal Wounding of the Apis Bull (Ca. 523 B. C. E.)', JNES 54, No. 2 (1995), 119. The Apis bull was the $b 3$ of the god Ptah of Memphis; in other words, it was the manifestation of Ptah's power. In the same way, the Buchis bull venerated at Armant was the $b a$ of the god Ra, and the sacred ram venerated at the city of Mendes was the $b 3$ of the god Osiris. These animals had special significance because only a single example of the species was considered to embody the $b 3$ of the deity at any one time. This unique creature could be recognised by special markings on the body. Once identified by the priests, it was installed in a temple until its death, when it received an individual burial with all the formalities accorded to a person of the highest status, including a relatively high standard of mummification; Taylor, Death and the Afterlife, 246; S. Pfeiffer, 'The God Serapis, his Cult and The Beginnings of The Ruler Cult in Ptolemic Egypt, Originalveröffentlichung', in: Paul McKechnie, Philipe Guillame (Hg.), Ptolemy II Philadelphus and his world (Mnemosyne: supplements Vol. 300) (Leiden, 2008), 389; H. Bonnet, Reallexikon der ägyptischen Religionsgeschichte (Berlin, 1952),46-50.

${ }^{13}$ Bread offering was one of imnyt of offerings. Although the most common depiction of a bread loaf was pyramidal in shape (known as the $t$-ḥd bread) shown resting on the palm of the offeror's hand, or representing word (di) meaning 'to give' $\Delta$ (Gardiner $\mathrm{X} 8$ ), Although this pyramid sign is shown to represent a specific form of bread used in offerings, it is also used to represent bread generally. There were in fact many different forms of bread types and shapes in ancient Egypt. A list of offerings to Amun-Ra from Ramesses III names a number of different types and in tombs some wall scenes show the bread-making process and the variety of bread shapes made such as loaves which were roughly circular or ovoid with slashes to allow the gas formed during fermentation and baking escape. There was also a flat loaf that was often curved, having taken the shape of the inner wall of the cylindrical oven where it was baked. A variety that had in its centre a carter surrounded by a raised or everted lip. These shapes include spherical shaped loaves and can be supported by the preservation of real bread loaves from sites such as Deir elMedina. For more see, M. Poo, 'Liquids in Temple Ritual', in Willeke Wendrich (ed.), UCLA Encyclopedia of Egyptology (Los Angeles, 2010), 5; A. Hammett, The Use of Clay Balls In Ancient Egypt: A ritual of fertility, rite of passage and a contractual agreement? (MA, diss., University of Kent, 2017), 315, 317, 318; Wb I, 8384; D. Samuel, 'A new look at old bread: ancient Egyptian baking', Archaeology International 3 (1999), 28-31; D . Samuel, 'Their staff of life: initial investigations on ancient Egyptian bread baking', in Amarna Reports V,
} 
markings. ${ }^{14}$ It would be the same with its forms in several stelea such as; Louvre IM. $4030^{15}$, and Louvre IM. 4109. ${ }^{16}$ The upper part of the bull Apis with a disc between two horns. ${ }^{17}$

As may be seen in the photo (fig. 1) the most prominent manifestation of the ritual association is the offering from htp table, which was a very traditional shape, having its origins as far back as the Old Kingdom. ${ }^{18}$

\section{Transcription, Transliteration, and Translation of the Middle Text:}

- Horizontal right to left:

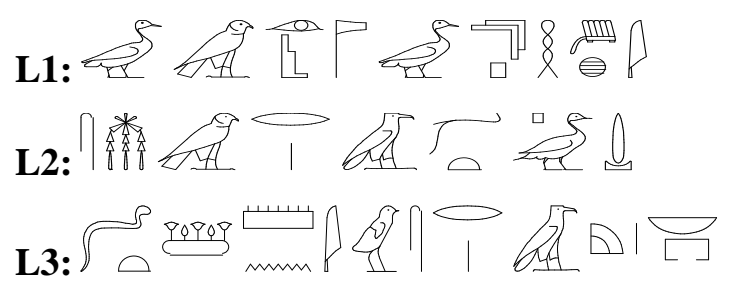

L1: $\operatorname{im} 3 h(w) h r H p^{19} W \operatorname{sir} H r-w^{20}$

L2: $\underline{d} 3$ s3 Ns-t3-ri.t- $H r^{21} m s .<n>$

B. J. Kemp (ed.) (London, 1989), 253-290; F. Leek, 'Teeth and bread in ancient Egypt', Egypt Archaeol 58 (1972), 126-132; W. J. Darby et al., Food: the gift of Osiris II (London, 1977), 501-528. For all types of bread. See, M. Mehdawy et al, The Pharaoh's Kitchen: Recipes from Ancient Egypt's Enduring Food Traditions (Cairo, 2010), 31-32.

${ }^{14}$ The certain marks of Apis appeared since the first dynasty, where a limestone fragment found in Hemaka's tomb provides the first clue. On this fragment, we see a bull whose neck, chest, a small circle on the back and the rump are black. Those areobviously the original signs of the bull Apis, which were later developed according to the change that occurred in the theology of Apis from the New Kingdom. Although it is impossible to verify the exact nature of the double hairs of the tail and the existence of a beetle under the tongue, the monuments that figure this animal and which are dated XVIII dynasty until the Greek and Roman periods. See M. I. Aly, 'Documents inedits provenant des petits souterrains du Serapeum de Memphis (textes et commentaire)', MDAIK 62 (2006), 51-52.

${ }^{15}$ Vercoutter, Textes biographiques du Sérapéum, 82-87 Doc. M, pl. xii.

${ }^{16}$ Vercoutter, Textes biographiques du Sérapéum, 78-82 Doc. L, pl. xi; Aly, MDAIK 62 (2006), 51-52.

${ }^{17}$ This member was distinguished by specific marks indicating the intervention of a certain god in the choice of this animal to represent it. Apis was believed to be incarnate in a bull, born to a virgin cow which was supposed to have been impregnated by Ptah through the agency of fire from heaven (perhaps a bolt of lightning); It was chosen by priests who travelled throughout Egypt searching for the new-born calf which was the incarnation of Apis. We have no Egyptian text evoking his choice and his marks. Thus, we rely solely on Classical writers. According to Herodotus, this calf was identified by means of specific body markings. The hide of the bull was black, with a white triangle on the forehead, and a mark shaped like an 'eagle' on the back, while 'double hairs' were to be found in the tail and a scarab beetle-shaped mark on the tongue. Bronze figurines of the later first millennium BC show the triangular mark on the forehead, and a vulture and a winged scarab or sundisc on the back, but paintings of the Apis on coffins from the same general period usually depict it as pied rather than black. Once identified, the bull was taken in procession to the temple of Ptah at Memphis. Here he was formally inaugurated, and began a life of luxury, pampered by attendants and fed on the richest foods in a special temple of his own, where he received the veneration of worshippers. See, Taylor, Death and the Afterlife, 247, fig. 182; A. Dodson, 'Rituals Related to Animal Cults', in Jacco Dieleman, Willeke Wendrich (eds.), UCLA Encyclopedia of Egyptology (Los Angeles, 2009), 2; Aly, MDAIK 62 (2006), 51-52.

${ }^{18}$ For more kinds of offering tables. See, D. B. Redford, offerings; offering tables, The Oxford Encyclopedia of Ancient Egypt (oxford, 2001), 572-576.

${ }^{19}$ For the most complete list of known Apis bulls during the Pharaonic and Ptolemaic times. See, A. Dodson, 'Bull Cults', in S. Ikram (ed.), Divine Creatures. Animal Mummies in Ancient Egypt (Cairo, 2005), 9091, with additional comments in P. Meyrat, 'The First Column of the Apis Embalming Ritual Papyrus Zagreb 597-2', in J. F. Quack(ed.), Ägyptische Rituale der griechisch-römischen Zeit (Tübingen, 2014), 263-337.

${ }^{20} \mathrm{PN}, 1.88$ (no. 26). 


\section{L3: $n b(. t) \operatorname{pr} K\{3\} r=s w-<r>-\operatorname{Tmn} \$ 3 d t^{22}$}

L1: The revered one before Apis, the Osiris of Horwe-

L2: dja, son of Nestarithor, whom

L3: the lady of the house Qerswamun bore Forever.

\section{Textual Notes:}

- im $3 h w(+h r, n)$ : (backbone with spinal cord issuing from it) ${ }^{23}$, it means the honoured one, revered, venerated, the one who has been provided for, endowed (with the means). ${ }^{24}$ It is worthy of mentioning that the im3hw hr formula could be used for deities, kings and ordinary persons. This formula was an ordinary formula that sometimes could be used by the deceased wishing to be honoured. ${ }^{25}$

-Wsir-hp: The designation Apis-Osiris (hp-Wsir) is much rarer in ancient times. It is a form of the god of the dead. It becomes, transformed, acting in Osiris. This formula attested since the Eighteenth Dynasty, it is the most common designation of the dead Apis bull having become Osiris (analogous to Osiris NN) while Wsir-hp is usually reserved for the syncretistic funerary deity. Occasionally, however, the terminological boundaries become blurred While Apis' theological connexion with Ptah remained rather loose, his association and partial syncretism with Osiris as Apis-Osiris and Osiris-Apis/ Osorapis/ Sarapis respectively grew in importance during the late second and first millennium BCE, eventually becoming momentous even beyond Egypt proper. ${ }^{26}$ When it died, every Apis bull was transformed into the deity Osiris- Apis. ${ }^{27}$ The use of OsirisApis is more frequent than that of Apis-Osiris on the ancient documentation of the Serapeum (from Amenhotep III), whereas, on the Ptolemaic stelae invoking the divinities, it is always Apis-Osiris which is employed. ${ }^{28}$

\footnotetext{
${ }^{21} P N, 1.179$ (no. 21).

${ }^{22} P N, 1.335$ (no. 28).

${ }^{23}$ A. Gardiner, Egyptian Grammar: Being an Introduction to the Study of Hieroglyphs (Oxford, 2007), 465.

${ }^{24}$ D. Jones, An Index of Ancient Egyptian Titles, Epithets and Phrases of the Old Kingdom (Oxford, 2000), $11 ; F C D, 20 ;$ Wb. I, 81[16];

${ }^{25}$ A. K. Eyma and C. J. Bennett, Delta-man in Yebu (Water Circle, 2003), 26-27. On im3hw see, A. Moret, 'La Condition des Féaux', RT 19 (1897), 121-123; W. Helck, 'Wirtschaftliche Bemerkungen zum privaten Grabbestiz im Alten Reich', MDAIK 14(1956), 68-70; H. G. Fischer, 'Two Old Kingdom Inscriptions Restored', JEA 65 (1979), 45-46; Jones, An Index of Ancient Egyptian Titles, 11-43; LÄ 6, 989-992.

${ }^{26}$ Bonnet, Reallexikon der ägyptischen, 48; D. Devauchelle, 'Une invocation aux dieux du Sérapéum de Memphis', in: W. Clarysse, A. Schoors et H. Willems (ed.), Egyptian Religion. The Last Thousand Years, Part I, Studies Dedicated to the Memory of Jan Quaegebeur (OLA 84) (Louvain, 1998), 593-595; Jurman, in: Bares et al (eds.), Egypt in Transition, 227 no.20.

${ }^{27}$ Pfeiffer, in: Paul McKechnie, Philipe Guillame (Hg.), Ptolemy II Philadelphus and his world, 389.

${ }^{28}$ Kh. El-Enany, 'Fragment d'Une Stéle d'Apos Mentionnant Le Roi Téti (Cairo JE 40044)', RdE 61 (2010), 80 .
} 
- The writing of the name of Osiris with the sign $\mid$, as determinative is a criterion inscription to the Saite and post-Saite period. ${ }^{29}$ Here it is placed before $\int$, which shows the back of the throne in a distinctive manner. ${ }^{30}$

- 14 : There were two forms of this name ' $H r$ - $w \underline{d}{ }^{\prime}$ ' and ' $w \underline{d} 3-H r^{\prime 31}$, the form which is used here is ' $H r-w d{ }^{\prime}$ ', where ' $H r$ ' is following the rule of orthography, wherever the divine name stands first, it does so merely in order to satisfy a well-known rule of orthography, which demands that divine or royal names, and the words for king and god, should precede in writing (though not in pronunciation). ${ }^{32}$ while the form ' $w \underline{d} 3-H r^{\prime}$ which is very popular in Apis stelea in $26^{\text {th }}$ and $27^{\text {th }}$ dynasties (e.g., in the Stela of ${ }^{C} n h-w n-n f r$ which is dating in the year 20 of Psamthek $\mathrm{I}^{33}$, the stela of $w \underline{d} 3-h r$, Louvre IM 3071 Attributable to Year 20/21 of Psamthek $\mathrm{I}^{34}$, the stela of $d i-n b$-wn, Louvre IM 3042 Attributable to Year 20/21 of Psamthek $\mathrm{I}^{35}$, and the stela of the members of the phyles of a priesthood, Louvre IM 4054 Year 4 of Darius) ${ }^{36}$, is one of the rare cases in which the scribe has so far liberated himself from orthographic considerations as to place the divine name in its proper grammatical position after the words. ${ }^{37}$

- $n b(t) p r$ : This title 'Lady of the House' is first attested in the Middle Kingdom and was used continually through the Ptolemaic Period. ${ }^{38}$ How this title has been understood in Egyptological thought differs from scholar to scholar. Lady of the House has been

${ }^{29}$ H. S. Smith et al, 'A Stela of the Persian Period from Saqqara', JEA 81 (1995), 34.

${ }^{30}$ Gardiner, Egyptian Grammar, 500; The name of Osiris is simplified also into a banal graphism on the stelae of this period (XXVI ${ }^{\text {th }}$ dynasty). See, Stela Nr. 18459 ( 24 year Taharqa); Aly, MDAIK 62 (2006), 46.

${ }^{31}$ PN I, 88. See also, A. Kamal, Stèles Ptolémaïques et Romaines I (Le Caire, 1905), 202-203 Nr. 22210.

${ }^{32}$ A. H. Gardiner and N. de G. Davies, The Tomb of Amenemhet (No. 82), TTS 1 (London, 1915), 80. For sign (fire drill) Gardiner list (U 28). Hence phon $(\underline{d})$ in ${ }^{U}(\underline{d} 3)$ which means 'ferry across' and in

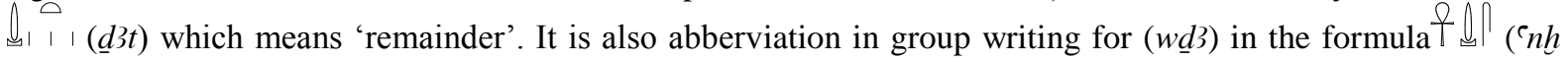
wd 3 snb). See, Gardiner, Egyptian Grammar, 519; Lesko, 120-121.

${ }^{33}$ Malinine, et al., Catalogue des stèles du Sérapéum de Memphis I, 166; PM III'2, 792; Labudek, Late Period Stelae from Saqqara, 118-120.

${ }^{34} \mathrm{PM}$ III $^{2}, 796$, Labudek, Late Period Stelae from Saqqara, 233.

${ }^{35}$ See, Labudek, Late Period Stelae from Saqqara, 238; Malinine, et al., Catalogue des stèles du Sérapéum de Memphis I, 162; $\mathrm{PM} \mathrm{III}^{2}, 796$.

${ }^{36}$ Labudek, Late Period Stelae from Saqqara, 273-274; PM III'2 799.

${ }^{37}$ Gardiner and N. de G. Davies, The Tomb of Amenemhet, 80.

${ }^{38}$ J. Toivari-Viitala, Women at Deir el-Medina: A Study of the Status and Roles of the Female Inhabitants in the Workmen's Community during the Ramesside Period. Egyptologische Uitgaven, 15 (Leiden, 2001 ), 15. The title frequently and perhaps inappropriately translated as a housewife (a decidedly modern and western concept, and not particularly descriptive of what the title actually entailed). Some one held this title concurrently with a priestly title. How ever, these were hardly the only occupations available to women nor were these occupations as simple as they seem at first glance. See, J. Johnson, The Social, Economic, and Legal Status of Women in Ancient Egypt, in The Life of Meresamun: A Temple Singer in Ancient Egypt, OIP 29 (Chicago, 2009), 86. 
typically understood as equivalent to the contemporary title of 'Mrs', that is, indicating a woman's married status. ${ }^{39}$ Alternatively, the term may be translated as 'owner of a house'. 40

VII. Transliteration, and Translation of the Lower Text (The Demotic inscription):

- Horizontal right to left:

\begin{tabular}{|l|l|l|}
\hline & Transliteration & Translation \\
\hline $\mathbf{L 1}$ & $H p \ldots \ldots$ & Apis ... \\
\hline $\mathbf{L 2}$ & $i y(?) \ldots r-r=f \ldots$ & $\begin{array}{l}\text { come(?) ... concerning (vel } \\
\text { sim.) him ... }\end{array}$ \\
\hline $\mathbf{L 3}$ & $\ldots \ldots \ldots$ & \\
\hline
\end{tabular}

VIII. Text Notes:

- Unfortunately, the demotic text is so damaged and faded that hardly anything can be made out of it. The first word is clear, and it is Apis (as in the hieroglyphic text); this thus confirms the stela's Apis-connection. There should be mention of the stela owner, Horwedja, and of his parents in the demotic text too. However, the text is so compromised; it is hard even to just identify those.

- The researcher connected with Prof. Dr Joachim Friedrich Quack ${ }^{41}$ and Dr Luigi Parada ${ }^{42}$, in Regarding this demotic text, and they said the text is in place too faint for clear reading. Hereafter their provisional proposals:

${ }^{39}$ W. Ward, Essays on Feminine Titles of the Middle Kingdom and Related Subjects (Beirut, 1986), 8. If the Lady of the House was a title that referred to the married state, then we can now discuss the roles that wives assumed in the household. Ladies of the House were responsible for running various aspects of the household, which could consist of the nuclear and extended family. An elite or well-off Lady of the House supervised a large number of staff and activities, while in homes of lower standing, the Lady of the House would be responsible for the actual production of the goods necessary for the household. She would weave, grind and bake bread, brew beer and perhaps shop, sell or barter for other products. A Lady of the House also could manage, inherit and act as trustee of marital property. See, G. Robins, Women in Ancient Egypt (London, 1993), 99, 104; J. Li, Women, Gender and Identity in Third Intermediate Period Egypt (New York, 2017), 29.

${ }^{40}$ Johnson, The Social, Economic, 86.

${ }^{41}$ Prof. Dr. Joachim Friedrich Quack: Ägyptologisches Institut Voßstr. 2, Gebäude 4410 D-69115 Heidelberg.

${ }^{42}$ Dr. Luigi Prada: British Academy Research Fellow in Egyptology, Faculty of Oriental Studies, University College, University of Oxford. Mailing Address: University College, High Street, Oxford OX1 4BH, United Kingdom. 
- Line 1: $h p$ di.t ' $n h$ "Apis gives life", then several illegible groups (probably a name with filiation), the something which might be the 1. ps. of the conjunctive $m t w=y$.

- Line 2: iy $r . r=s$ "(will) come against it", then perhaps $r k$ "remove" (but reading very doubtful), after a few problematic signs perhaps the suffix $=f$, and then $h r$ nti bn $r . r=f$ "with what is bad against him". The final word perhaps $n h m$ "save" (if the determinative is lost).

- Line 3, it still has serious difficulties.

\section{Dating:}

The stela is dating by $\mathrm{XXVI}^{\text {th }}$ or XXVII ${ }^{\text {th }}$ dynasties, where the general style and iconography of the figures suggested that. Especially:

- Some details and features of the figures in the offering scene.

- Epigraphic idiosyncracies of the hieroglyphic text (the writing of the name of the god Apis-Osiris which seems to be known only from the saite period.

- Moreover, it is most often in this form Apis-Osiris that the name is written following the sequence Im3hw $(h r)$ on the Serapeum stelae dated XXVI ${ }^{\text {th }}$ $\mathrm{XXX}^{\text {th }}$ dynasties $)^{43}$, and perhaps certain palaeographical indications in the Demotic.

\section{Conclusion:}

According to the categories of Serapum stelae, the stela owner, Horwedja seemed to be one of the masons or the workers in the burial vaults. They dedicated stelae with traditional funerary offering scenes for Apis Bull, as it was the emanation and embodiment of the god Ptah.

Finally, the design, layout, inscription, the appearance of the figures and the details of the offering scene in the main scene, epigraphic idiosyncracies of the hieroglyphic text of the stela suggested the $26^{\text {th }}$ Dynasty or $27^{\text {th }}$ dynasty as the nearest date.

\footnotetext{
${ }^{43}$ El-Enany, RdE 61 (2010), 82-83.
} 


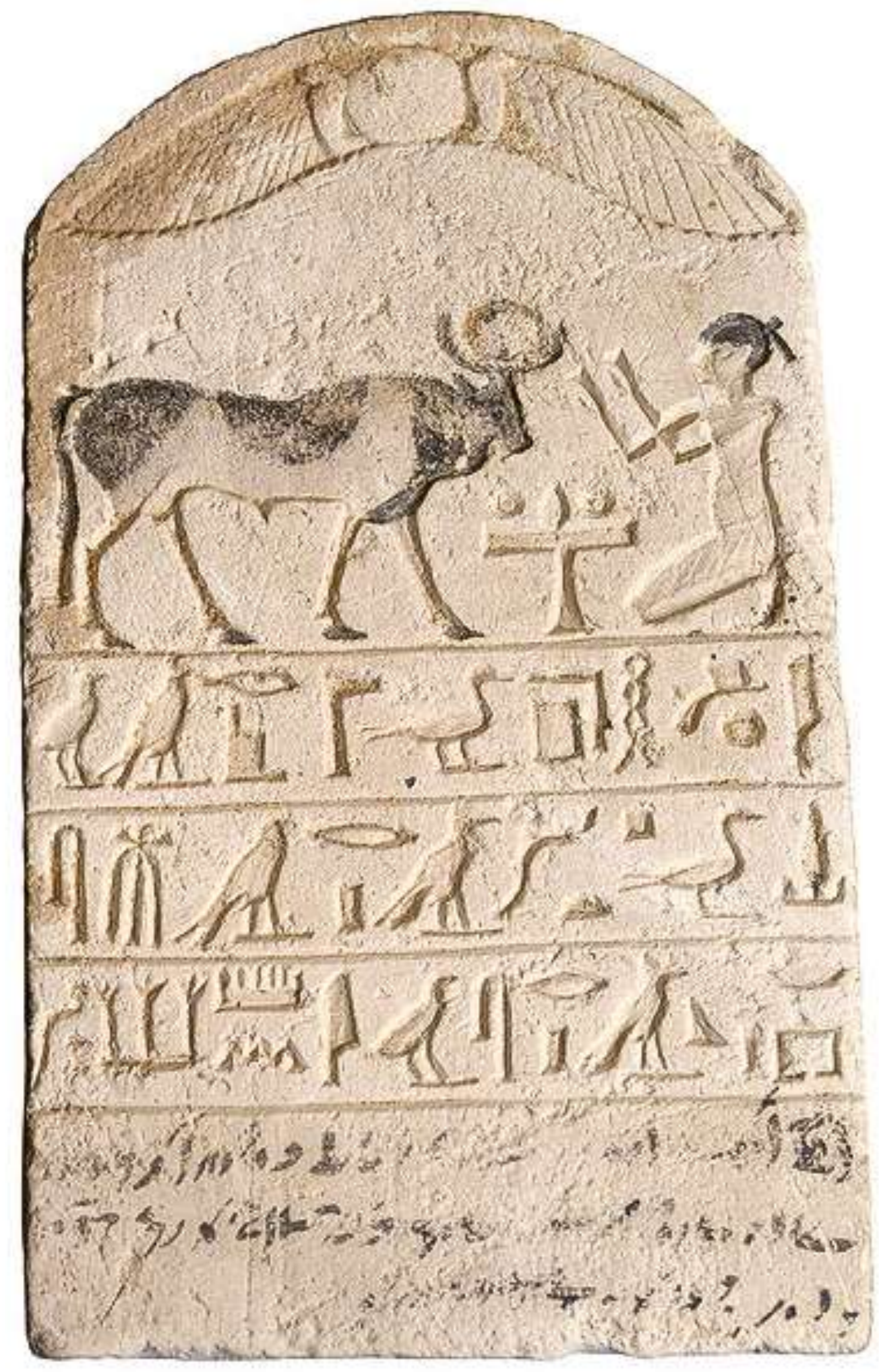

(pl. 1) 


\section{Abbreviation:}

- EJARS: Egyptian Journal of Archaeological and Restoration Studies.

- FCD: Faulkner (R.O.), Concise Dictionary of Middle Egyptian, 1962 (Oxford)

- JEA: Journal of Egyptian Archaeology. Egypt Explor. Soc. (Londres).

- JAEA: The Journal of Ancient Egyptian Architecture [South Burlington, Vermont]: [David Ian Lightbody], 2016-

- JNES: Journal of Near Eastern Studies. Dept. of Near Eastern Lang. and Civilis., univ. de Chicago (Chicago, Ill.).

- L̈̈: Lexikon der Ägyptologie (Wiesbaden).

- MDAIK: Mitteilungen des deutschen archäologischen Instituts, Abt. Kairo (Wiesbaden, Mayence)

- OIP: Oriental Institute Publications. Univ. de Chicago (Chicago, Ill.)

- PM: Porter (B.), Moss (R.L.B.), Topographical Bibliography of Ancient Egyptian Hieroglyphic Texts, Reliefs and Paintings, 7 vol., 1927-1995 (Oxford)

- PN: Ranke (H.), Die ägyptischen Personennamen, 3 vol., 1935-1977 (Glückstadt, Hambourg)

- $\boldsymbol{R T}$ : Recueil de travaux relatifs à la philologie et à l'archéologie égyptiennes et assyriennes (Paris).

- Wb: Erman (A.), Grapow (H.), Wörterbuch der ägyptischen Sprache, 1926-1963 (Leipzig, Berlin) 


\section{Bibliography:}

1. Alam, M., 'Kors El-shams (Al-Moganah) zo el-genah alwahed wa ain alwogadat ala kemam al-lawhat', CAHIER 37 (2008), 103-113.

2. Aly, M. I., 'Documents inedits provenant des petits souterrains du Serapeum de Memphis (textes et commentaire)', MDAIK 62 (2006), 43-61.

3. Bonnet, H., Reallexikon der ägyptischen Religionsgeschichte (Berlin, 1952).

4. Darby W. J., et al., Food: the gift of Osiris II (London, 1977).

5. Depuydt, L., 'Murder in Memphis:The Story of Cambyses's Mortal Wounding of the Apis Bull (Ca. 523 B. C. E.)', JNES 54, No. 2 (1995), 119-126.

6. Devauchelle, D., 'Une invocation aux dieux du Sérapéum de Memphis', in: W. Clarysse, A. Schoors et H. Willems (ed.), Egyptian Religion. The Last Thousand Years, Part I, Studies Dedicated to the Memory of Jan Quaegebeur (OLA 84) (Louvain, 1998).

7. Dodson, A., 'Bull Cults', in S. Ikram (ed.), Divine Creatures. Animal Mummies in Ancient Egypt (Cairo, 2005).

8. 'Rituals Related to Animal Cults', in Jacco Dieleman, Willeke Wendrich (eds.), UCLA Encyclopedia of Egyptology (Los Angeles, 2009), 1-8.

9. El-Enany, Kh., 'Fragment d'Une Stéle d'Apos Mentionnant Le Roi Téti (Cairo JE 40044)', RdE 61 (2010), 77-89.

10. El-Toukhy, M., 'Protection Symbols on The Top of The Middle Kongdom Stelae (in Cairo Museum)', EJARS 3 (2013), 131-137.

11. Eyma A. K., and Bennett, C. J., Delta-man in Yebu (Water Circle, 2003).

12. Fischer, H. G., 'Two Old Kingdom Inscriptions Restored', JEA 65 (1979), 4246. 
13. Gardiner, A. H., and de G. Davies, N., The Tomb of Amenemhet (No. 82), TTS 1 (London, 1915).

14 Egyptian Grammar: Being an Introduction to the Study of Hieroglyphs (Oxford, 2007).

15. Hammett, A., The Use of Clay Balls In Ancient Egypt: A ritual of fertility, rite of passage and a contractual agreement? (MA, diss., University of Kent, 2017).

16. Helck, W., 'Wirtschaftliche Bemerkungen zum privaten Grabbestiz im Alten Reich', MDAIK 14(1956), 63-75.

17. Hölzl, R., 'Round-Topped Stelae from the Middle Kingdom to the Late Period, Remarks on the Decoration of the Lunettes', SCIE I (1992), 285-290.

18. ............ 'Stelae', in: Oxford Encyclopedia of Ancient Egypt III (Oxford, 2001), 319-324.

19. Johnson, J., The Social, Economic, and Legal Status of Women in Ancient Egypt, in The Life of Meresamun: A Temple Singer in Ancient Egypt, eds. E. Teeter and J. Johnson, OIP 29 (Chicago, 2009).

20. Jones, D., An Index of Ancient Egyptian Titles, Epithets and Phrases of the Old Kingdom (Oxford, 2000).

21. Jurman, C., Running with Apis The Memphite Apis Cult as a Point of Reference for Social and Religious Practice in Late Period Elite Culture, in: Bares et al (eds.), Egypt in Transition (Prague, 2010), 225.

22. Kamal, A., Stèles Ptolémaïques et Romaines I (Le Caire, 1905).

23. Labudek, J., Late Period Stelae from Saqqara; A socio-Cultural and Religious Investigation (MA. diss., The University of Birmingham, 2010). 
24. Leek, F., 'Teeth and bread in ancient Egypt', Egypt Archaeol 58 (1972), 126132.

25. Li, J., Women, Gender and Identity in Third Intermediate Period Egypt (New York, 2017).

26. Malinine, M., et al., Catalogue des stèles du Sérapéum de Memphis I (Paris, 1968).

27. Marković, N., 'A look through his window: the sanctuary of the divine Apis Bull at Memphis', JAEA 1(2016), 57-70.

28. Marković, N., 'The Cult of The Scared Bull Apis: History of Study', in: A History of Research into Ancient Agyptian Culture Conducted in Southeast Europe, ed. M. Tomorad (Oxford, 2015).

29. Mehdawy, M., et al., The Pharaoh's Kitchen: Recipes from Ancient Egypt's Enduring Food Traditions (Cairo, 2010).

30. Meyrat, P., 'The First Column of the Apis Embalming Ritual Papyrus Zagreb 597-2', in J. F. Quack(ed.), Ägyptische Rituale der griechisch-römischen Zeit (Tübingen, 2014).

31. Moret, A., 'La Condition des Féaux', RT 19 (1897), 121-148.

32. Müller, H. W., 'Die Totengedenksteine des Mittleren Reiches, ihre Genesis, ihre Darstellungen und ihre Komposition', MDAIK 4 (1933), 165-206.

33. Pfeiffer, S., God Serapis, His Cult and the Beginnings of the Ruler Cult in the Ptolemaic Egypt, Originalveröffentlichung in: Paul McKechnie, Philipe Guillame (Hg.), Ptolemy II Philadelphus and his world (Mnemosyne: supplements Vol. 300) (Leiden; Boston 2008).

34. Pfeiffer, S., 'The God Serapis, his Cult and The Beginnings of The Ruler Cult in Ptolemic Egypt, Originalveröffentlichung', in: Paul McKechnie, Philipe 
Guillame (Hg.), Ptolemy II Philadelphus and his world (Mnemosyne: supplements Vol. 300) (Leiden, 2008).

35. Poo, M., 'Liquids in Temple Ritual', in Willeke Wendrich (ed.), UCLA Encyclopedia of Egyptology (Los Angeles, 2010), 1-7.

36. Redford, D. B., offerings; offering tables, The Oxford Encyclopedia of Ancient Egypt (oxford, 2001).

37. Robins, G., Women in Ancient Egypt (London, 1993).

38. Samuel, D., 'Their staff of life: initial investigations on ancient Egyptian bread baking', in Amarna Reports V, B. J. Kemp (ed.) (London, 1989).

39. .........., 'A new look at old bread: ancient Egyptian baking', Archaeology International 3 (1999), 28-31.

40. Shonkwiler, R. L., The Behdetite: A Study of Horus The Behdetite from The Old Kingdom to The Conquest of Alexander (Ph. D. diss., Chicago, 2014).

41. Simpson, W. K., 'A running of the Apis in the reign of 'Aha and passages in Manetho and Aelian', Orientalia 26 (1957), 139-142.

42. Smith, H. S., et al., 'A Stela of the Persian Period from Saqqara', JEA 81 (1995), 23-42.

43. Taylor, J. H., Death and the Afterlife in Ancient Egypt (London, 2001),

44. Thompson, D. J., Memphis under the Ptolemies (Princeton, 1988).

45. Toivari-Viitala, J., Women at Deir el-Medina: A Study of the Status and Roles of the Female Inhabitants in the Workmen's Community during the Ramesside Period. Egyptologische Uitgaven, 15 (Leiden, 2001).

46. Vercoutter, J., Textes biographiques du Sérapéum de Memphis; Contributions à l'étude des stèles votives du Sérapéum (Paris, 1962). 
47. Ward, W., Essays on Feminine Titles of the Middle Kingdom and Related Subjects (Beirut, 1986). 